\title{
Knowledge and attitude towards HIVIAIDS among Iranian students
} Anahita Tavoosi*, Azadeh Zaferani, Anahita Enzevaei, Parvin Tajik and Zahra Ahmadinezhad

Address: Tehran University of Medical Sciences, Tehran, Iran

Email: Anahita Tavoosi* - atavoosi@sina.tums.ac.ir; Azadeh Zaferani - azinazius@yahoo.com; Anahita Enzevaei - anita_soleil@yahoo.com; Parvin Tajik - tajik_p@yahoo.com; Zahra Ahmadinezhad - ahmadiz@sina.tums.ac.ir

* Corresponding author

Published: 24 May 2004

BMC Public Health 2004, 4:17
Received: 19 December 2003

Accepted: 24 May 2004

This article is available from: http://www.biomedcentral.com/I47I-2458/4//7

(C) 2004 Tavoosi et al; licensee BioMed Central Ltd. This is an Open Access article: verbatim copying and redistribution of this article are permitted in all media for any purpose, provided this notice is preserved along with the article's original URL.

\begin{abstract}
Background: Young people are of particular importance in state policies against Acquired Immunodeficiency Syndrome (AIDS). We intended to assess the knowledge and attitude of high school students regarding AIDS in Iran.
\end{abstract}

Methods: Through a cluster-sampling, 464I students from 52 high schools in Tehran were assessed by anonymous questionnaires in February 2002.

Results: The students identified television as their most important source of information about AIDS. Only a few students answered all the knowledge questions correctly, and there were many misconceptions about the routes of transmission. Mosquito bites (33\%), public swimming pools (21\%), and public toilets $(20 \%)$ were incorrectly identified as routes of transmission. $46 \%$ believed that Human Immunodeficiency Virus positive (HIV positive) students should not attend ordinary schools. Most of the students wanted to know more about AIDS. In this study knowledge level was associated with students' attitudes and discipline $(\mathrm{p}<0.00 \mathrm{I})$.

Conclusion: Although the knowledge level seems to be moderately high, misconceptions about the routes of transmission were common. There was a substantial intolerant attitude towards AIDS and HIV positive patients. We recommend that strategies for AIDS risk reduction in adolescents be developed in Iranian high schools.

\section{Background}

The Acquired Immunodeficiency Syndrome (AIDS) epidemic is in its third decade and has become a pandemic disease that threatens the world population. It affects all body systems as well as the mental health and social relationships of carriers and asymptomatic patients.

In Iran the first case of Human Immunodeficiency Virus (HIV) was reported in 1987 . This was followed by a rapid increase in the number of cases. In 2003, officially there were 5086 Iranians living with HIV/AIDS, of which, 4838 were male and 248 were female. According to official data in Iran, $67 \%$ of AIDS patients are intravenous drug users and $9 \%$ were infected by sexual contact. There are some $17 \%$ of cases grouped under "unspecified" route of transmission. It is feared that the HIV/AIDS situation in Iran may be more serious than these published data indicate, and the main concern is the potential spread of infection 
from injecting drug users to the general population. The strategic geographic situation of Iran and its long borders with the countries of the Golden Crescent (Afghanistan and Pakistan), which produce a substantial proportion of the world's heroin, have confronted Iran with the problems of drug trafficking and concomitant drug addiction within the country $[1,2]$.

Statistics show that for five patients affected by AIDS, one is in his 20s [3,4]. Given the long incubation period of HIV, it is clear that many older adolescents and young adults with AIDS were infected as younger teenagers [5]. There are several factors that contribute to the higher risk of HIV infection among young people e.g. first sexual experiences, the higher proportion of sexually transmitted diseases, addiction that begins usually at this age, and so on [6]. On the other hand, there is a chance to establish protective health-behavior patterns in young people, which might endure into adulthood. Since there are uncontrolled sexual contacts, high prevalence of addiction, absence or limited sex education and higher marriage age in Iran, the Iranian youth are counted as a high risk group for HIV infection. It is obvious that against such a background the risk of HIV infection increases. Moreover, because of unreasonable fears among most Iranian people that AIDS education promotes high risk behaviors, sex education about HIV transmission has no place in schools and universities in Iran. Accordingly, the current HIV/AIDS situation and the fact that antiretroviral drugs are not affordable and available for treating vast numbers of HIV-positive individuals makes primary prevention of HIV infection seem the most important concept in controlling the epidemic [7].

In this study the common knowledge and attitude of a group of Iranian high school students about AIDS, transmission of HIV, and methods of prevention have been evaluated.

\section{Methods}

This cross-sectional study was conducted in February 2002 in the Iranian capital city, Tehran. Fifty-two out of 500 high schools in Tehran were randomly selected. All the second grade students of each school who were present in the classroom on the day of the research team's visit agreed to participate. The second grade high school students were selected because they had passed at least one year in high school, and were the most available students. The data was collected by self-administered anonymous questionnaires. The original questionnaire included 50 questions. Two epidemiologists, a specialist in infectious diseases, and a general physician reviewed the questionnaire. Only 20 close-ended questions were judged as valid and included in the study. These questions covered the following categories: demographic information, dis- ease knowledge including mode of transmission and high risk group population, attitudes towards HIV-positive patients, source of knowledge and willingness to learn. The questionnaire was pre-tested in one school and after analyzing the data, the Cronbach's $\alpha$ was calculated to assess the internal consistency of knowledge questions ( $\alpha$ $=0.67$ ). The qustions were answered using the options "Agree", "Disagree" and "I don't know". A total score for knowledge was obtained by adding the points given for each answer. For each correct answer 2 points, "I don't know" 1 point, and any incorrect answer zero points were assigned. The sum makes up the total score which ranged between 0 and 40. A higher score indicated a greater level of knowledge. The attitude score was computed similarly; a higher score reflects intolerance towards the infected patients, and maximal possible score was eight.

A sample size for the precision of 5\%, expected prevalence of $50 \%$, and confidence interval of $95 \%$ was calculated as 4000. The data was evaluated by Chi-square test, analysis of variance (one-way ANOVA) and Spearman's Correlation test using the Statistical Package of Social Science (SPSS Inc., Chicago, IL) for Windows version 10.0. A pvalue of $<0.05$ was considered statistically significant.

The Ministry of Education granted ethical approval. In addition, permission to carry out the research was obtained from the principals of the schools where the survey was performed. Students were informed that their participation was voluntary.

\section{Results}

A total of 4641 high school students (55\% female and $45 \%$ male) participated in the study (table 1 ). They were aged 15-17 years (mean, 16.2 years). Ninety four percent of students expressed a wish to know more about HIV/ AIDS. "Television and radio" were the main sources of information followed by "newspapers and magazines", "friends", "books", and "family" as stated by the participants. Only $6 \%$ of the students mentioned "teachers and schools" as the main source of information about HIV/ AIDS. Among these, "newspapers and magazines" were associated with the most knowledge scores $(\mathrm{p}<0.001)$.

The majority of students had accurate knowledge about HIV/AIDS modes of transmission (table 2), with $67-96 \%$ correctly answering each of questions. However, many misconceptions were still noted relating to HIV/AIDS, with $9 \%$ of students believing that children would never be affected by HIV/AIDS, 10\% believing that HIV-positive people can be recognized by their appearance, $9 \%$ and $11 \%$ believing that there is a cure and vaccine for AIDS respectively. 
Table I: Characteristics of the 464I High School Students Enrolled in the Study

\begin{tabular}{|c|c|c|c|}
\hline Characteristics & $\mathbf{n}$ & Mean \pm S.D. & $\%$ \\
\hline \multicolumn{4}{|l|}{ Gender: } \\
\hline Female & 2552 & & 55 \\
\hline Male & 2089 & & 45 \\
\hline \multicolumn{4}{|l|}{ Education Field: } \\
\hline Mathematics & $|63|$ & & 35 \\
\hline Applied Sciences & 1182 & & 26 \\
\hline Experimental Sciences & 931 & & 20 \\
\hline Social Sciences & 873 & & 19 \\
\hline No Response & 24 & & 0 \\
\hline Family Size (person) & & $5 \pm 1$ & \\
\hline
\end{tabular}

$\mathrm{n}=$ Number of students in each group

Table 2: Modes Transmission As Reported By the 464I High School Students (\%). Response to the Question "by which of the Following Ways Can HIV*IAIDS** be Transmitted?"

\begin{tabular}{lcc}
\hline & Students $\mathbf{n}=\mathbf{4 6 4} \mathbf{I}$ & Percent choosing correct answer \\
\hline \multicolumn{1}{c}{ Mode } & Correct answers & 96 \\
Sexual Contact & Yes & 94 \\
Blood transfusion & Yes & 93 \\
Sharing of the needles & Yes & 91 \\
Hand shaking & No & 91 \\
Shaver blade & Yes & 87 \\
Food-borne & No & 85 \\
Kissing and hugging & No & 83 \\
Mother-to-child & Yes & 81 \\
Tattoo & Yes & 80 \\
Public toilet & No & 79 \\
Public swimming pool & No & 77 \\
Sneezing and coughing & No & 74 \\
Dentistry & Yes & 67 \\
Mosquitoes bites & No & \\
\hline
\end{tabular}

*HIV, human immunodeficiency virus ** AIDS, acquired immunodeficiency syndrome

Female sex, family size, parents' education, and students' school discipline, though statistically significant $(\mathrm{p}<$ 0.01 ) were minimally associated with students' knowledge about HIV/AIDS.

In response to a question about the best way of fighting AIDS, $71 \%$ of the students believed that investment on youth education is the best method. However, vaccination and treatment of AIDS patients were also expressed by $10 \%$ and $4 \%$ respectively. Most of the students (93\%) believed that AIDS could be a threat to the Iranian population ( $94 \%$ of boys and $95 \%$ of girls).

Negative attitudes toward HIV-infected individuals were common. Forty six percent of students thought that a stu- dent with the disease should not be allowed to enter an ordinary school [boys and girls were the same for this attitude (50\% vs. $48 \%)]$. Thirty five percent of the students stated that they prefer not to sit in a class near an HIV positive student [no significant difference between boys and girls $(37 \%$ vs. $36 \%)]$. Twenty three percent of students indicated that they would not shake hands with an HIVpositive person if they knew about his or her disease [24\% of boys vs. $24 \%$ of girls]. Attitude was significantly correlated with knowledge $(r=-0.38, P<0.001)$; students with less knowledge scores had more negative attitude towards HIV positive patients.

Finally, as a supplemental question, the students were asked to express their feeling towards an HIV positive 
Table 3: Feelings of Students toward an Infected Person. Response to the Question "What are your Feelings toward a HIV*-Positive Person?"

\begin{tabular}{llll}
\hline $\begin{array}{l}\text { Feelings toward HIV-Positive } \\
\text { Patients }\end{array}$ & Females n(\%) & Males n(\%) & p-value \\
\hline Hatred & $355(15 \%)$ & $342(18 \%)$ & \\
Compassion & $1365(56 \%)$ & $924(47 \%)$ & $\chi^{2} 36.63 p<0.0001$ \\
Apathy & $697(29 \%)$ & $688(35 \%)$ & 1954 \\
Total & 2417 & & \\
\hline
\end{tabular}

*HIV, human immunodeficiency virus; $\mathrm{n}=$ Number of students expressed their feelings; $\mathrm{p}<0.05$ is considered significant.

person. Forty nine percent of the students would be compassionate to an infected person and $15 \%$ of them feel hatred towards him or her. Thirty percent of students would feel apathetic towards the HIV positive people. These feelings were different between boys and girls (Table 3). The girls were more compassionate to AIDS patients than boys $56 \%$ of girls vs. $47 \%$ of boys, $\mathrm{p}<$ $0.001)$.

\section{Discussion}

The present study evaluated the knowledge and attitude of Iranian high school students towards HIV-positive and AIDS patients. The reports concerning rapid spread of AIDS in various populations have increased the level of anxiety over contagion among adolescents. This may explain why about $94 \%$ of the students expressed a wish to obtain more information about AIDS, and most surveyed students believed that AIDS could be a threat to their society. This finding is similar to that of American and European investigators one decade ago, when the AIDS epidemic was emerging [8-10].

In general, the study revealed a variable lack of knowledge about HIV/AIDS among students. Female students demonstrated a slightly higher level of knowledge in comparison with male students; this difference is small and practically insignificant but consistent with the studies of Brook and Green et al $[11,12]$. However, Agrawal et al found that boys had better knowledge than girls and their explanation for this finding was that boys feel freer than girls to talk about matters relating to sex and HIV/AIDS [13].

The media (Television and radio) were the most common means of obtaining information about HIV/AIDS, but not the most credable sources. This was consistent with the study by Brook [11]. "Newspapers and magazines" were associated with the most accurate knowledge about HIV/ AIDS. Studies in Southeast Asia have shown that most media have done little to change existing cultural values and prejudice about the sexuality and the situation of people who are living with HIV or AIDS. They were good at educating people that HIV and AIDS exists but mainly in a frightening way because they have seldom given enough in-depth information to contextualize this information [14]. Taking everything into account, media should apply new methods of AIDS education to improve public knowledge about HIV/AIDS.

Overall, there were many misconceptions about how HIV is transmitted, e.g. by shaking hands, using public toilets, using public swimming pools, etc. This problem was also addressed by previous investigators such as Agrawal et al, DiCemente et al, and Sikand et al [[13,15], and [16]]. However Brook et al have found relatively sufficient knowledge about transmission and "high risk group population" among Israeli high school students [17]. In our study, a considerable proportion of respondents thought that there is a cure for AIDS. This is consistent with the findings of Agrwal et al, and can be attributed to the many false claims published in media and other modes of advertisement [13]. Misinformation concerning a "cure" for AIDS is one of the risk factors for contracting the disease.

Though better knowledge does not necessarily lead to behavioral changes [18-20], we believe that repeated talks with teachers and advisors in the classroom about this important subject would have some influence upon a certain percentage of the students.

In this study, there was a substantial negative (intolerant) attitude towards AIDS and HIV positive patients. About a third of the students expressed that they would avoid sitting near an infected student. This was found to be true in the study of Brook [11]. In the study of Merakou only a small percentage of the students $(5 \%)$ declared that they would reject their infected friends. This study was performed after 15 years of HIV/AIDS prevention in Grecian schools [21]. Approximately half of students in our study expressed that an infected student should not be allowed to enter an ordinary school. Similarly this was reported by a third of Indian students in the study of Agrawal [13]. This can be explained by the approximity of Iranian and 
Indian attitudes towards HIV/AIDS which is associated with the great taboo, sex (especially outside- marriagesex). These are serious attitudinal problems aroused by lack of education about AIDS and need to be addressed.

The present study is in agree with the findings by Agrawal et al, Brown et al, Krasnik et al, and Ross et al [13,22-24] who have reported a correlation between knowledge and attitude, but not with Brook, and Morton et al $[11,25]$.

The study reported here has confronted several limitations. First, in a religious society like Iran, the researchers are restricted in asking questions concerning students' sexual beliefs and behaviors. Second, the results of this study may only be generalized to similar populations of students. They may not be applicable to adolescents who are not attending school. Third, because of the self-report nature of the questionnaire, the honesty of students' responses may be questioned. However, the questionnaire was anonymous, which should have encouraged accurate and honest self-disclosure.

\section{Conclusion}

Students (as well as the general population) should be instructed about all aspects of AIDS by the media, which at present is the most frequent but not necessarily credable source of information. Coalition of the media, Non Governmental Organizations (NGOs) that are active in grass-roots level and the politician and religious leaders who understand what is at stake, are needed [14]. There should also be a big push to increase teaching efforts in schools. This type of information is also recommended in other studies [[23,26] and [27]]. There is considerable rationale to include HIV/AIDS education as an integral part of high school curriculum. Educational advisors, physicians and nurses should discuss with students modes of prevention of HIV contamination.

\section{Competing Interests}

None declared.

\section{Authors' Contributions}

Anahita Tavoosi participated in the design of study, acquisition of data, analysis and interpretation of data, drafting the article, and final approval of this version. Azadeh Zaferani and Anahita Enzevaei participated in the design of study, acquisition of data, interpretation of data, and drafting the article. Parvin Tajik participated in acquisition of data, analysis and interpretation of data, and drafting the article. Dr Zahra Ahmadinezhad participated in the design of study, interpretation of data, and final approval of this version. All authors read and approved the final manuscript.

\section{Acknowledgements}

This study was funded by the Vice-Chancellor for Research, and Students' Scientific Research Center of Tehran University of Medical Sciences. The authors wish to thank Drs Bahareh Azadi, Mohammad Tavakkoli, Valentina Nematian, for their kind cooperation in designing the questionnaire. We also thank Mr. Bahram Shiravi, Dr G. Davey-Smith, and Dr Mohammad Reza Mohebbi who kindly revised the manuscript.

\section{References}

I. Center for Disease Control, Office of the Deputy for Public Health, Ministry of Health and Medical Education of the I.R. Iran. HIVIAIDS in Iran (Cumulative Statistics). Tehran 2003. In Persian

2. American Iranian Council: Drug Use and HIVIAIDS in Iran [http://www.american-iranian.org/beta/publications.php?PressRe lease $=\mid \&$ PressReleaselD $=56$

3. Center for Disease Control and Prevention: U.S. AIDS cases reported through June 1993. HIVIAIDS Surveill Rep 1993, 5:10.

4. Smith KW, McGraw SA, Crawford SL, Costa LA, Mckinlay J: HIV risk among Latino adolescents in two New England cities. Am J Public Hlth 1993, 83:I395-1399.

5. Brooks-Gunn J, Furstenberg FF: Coming of the age in the era of AIDS: puberty, sexuality, and contraception. Milbank $Q 1990$, 68:59-84.

6. Sechrist W: Personalizing HIV infection: moving students closer to believing..." this could actually happen to me!". J HIVIAIDS Preven Educ Adoles Child 1997, I: 105-107.

7. Stratigos JD, Tzala E: Global epidemiology of HIV infection and AIDS. Clin Dermatol 2000, 18:38I-387.

8. Herlitz C, Brorsson B: AIDS in the minds of Swedish people: 1986-1989. AIDS 1990, 4:1011-1018.

9. Rich JA, Holmes MD, Hodges DM: Preferred sources of AIDS information, risk perceptions, and risk behaviors among inner-city community college students. J Natl Med Assoc 1996, 88:87-93.

10. Gallup Organization: AIDS. Ist annual George H. Gallup Memorial Survey. Gallup Rep 1988, 273: I-79.

II. Brook U: AIDS knowledge and attitudes of pupils attending urban high schools in Israel. Patient Educ and Couns 1999, 36:27I-278.

12. Green MS, Carmel S, Tsur S, Slepon R, Vardi D: Differences in general knowledge of AIDS, its transmission and prevention among Israelis aged 18-19 years. Eur J Pub Hlth 1991, I:75-78.

13. Agrawal HK, Rao RS, Chandrashekar S, Coulter JB: Knowledge of and attitude to HIVIAIDS of senior secondary school pupils and trainee teachers in Udupi District, Karnataka, India. Ann Trop Pediatr 1999, 19:143-149.

14. Wolffers I: Culture, Media, and HIVIAIDS in Asia. Lancet 1997, 349:52-54.

15. DiClemente RJ, Lanier MM, Horan PF, Lodico A: A comparison of AIDS knowledge, attitude and behaviors among incarcerated adolescents and public school sample in San Francisco. Am J Public Health 1991, 81:628-630.

16. Sikand A, Fisher M, Friedman S: AIDS knowledge, concerns, behavior changes among inner-city high School students. J Adolesc Health 1996, 18:325-328.

17. Brook U, Heim M, Alkalay Y: Attitude and knowledge of high school pupils in Holon(Israel) towards AIDS. Israel J Med Sci 1994, 30:699-705.

18. Rubin Stiffman A, Earls F, Dore P, Cunningham R: Changes in AIDS related risk behavior after adolescence: relationships to knowledge and experience concerning HIV infection. Pediatrics 1992, 89:950-966.

19. Turner C, Miller H, Moses L, Eds: AIDS: Sexual Behavior and Intravenous Drug Use Washington DC: National Academy Press; 1989.

20. Brown LK, Fritz GK: Children's knowledge and attitudes about AIDS. J Am Acad Child Adolesc Psychiatry 1988, 27:504-508.

21. Merakou K, Costopoulos C, Markopoulou J, Kourea-Kremastinou J: Knowledge, attitudes, and behavior after 15 years of $\mathrm{HIVI}$ AIDS prevention in schools. Eur J public Health 2002, I 2:90-93.

22. Brown LK, Nessau JH, Barone VC: Differences in AIDS knowledge and attitude by grade level. J School Hlth 1990, 60:270-275.

23. Krasnik A, Wangel M: AIDS and Danish adolescence-knowledge, attitudes and behavior relevant to the prevention of HIV infection. Dan Med Bull 1990, 37:275-279. 
24. Ross MW: Distribution of knowledge of AIDS: a national study. Soc Sci Med 1988, 27:1295-1298.

25. Morton AD: Attitudes to and knowledge about the AIDS lack of a correlation. $B M J$ I986, 293: 1212 .

26. DiClemente RJ: Preventing HIVIAIDS among adolescents: Schools as agents of behavior change. JAMA 1993, 270:760-762.

27. Holtzman D, Lowry R, Kann L, Collins JL, Kolbe LJ: Changes in HIVrelated information - Sources, instruction, knowledge and behavior among US high school students, 1989 and 1990. Am J Pub Health 1994, 84:388-393.

\section{Pre-publication history}

The pre-publication history for this paper can be accessed here:

http://www.biomedcentral.com/1471-2458/4/17/prepub

Publish with Bio Med Central and every scientist can read your work free of charge

"BioMed Central will be the most significant development for disseminating the results of biomedical research in our lifetime. "

Sir Paul Nurse, Cancer Research UK

Your research papers will be:

- available free of charge to the entire biomedical community

- peer reviewed and published immediately upon acceptance

- cited in PubMed and archived on PubMed Central

- yours - you keep the copyright

Submit your manuscript here:

http://www.biomedcentral.com/info/publishing_adv.asp 